\title{
Coagulation Monitoring Devices: Past, Present, and Future at the Point of Care
}

\author{
Leanne F. Harris \\ Technological University Dublin, leanne.harris@tudublin.ie \\ Vanessa Castro-Lopez \\ CIC microGUNE \\ Tony J. Killard \\ University of the West of England, Bristol
}

Follow this and additional works at: https://arrow.tudublin.ie/scschbioart

Part of the Biology Commons

\section{Recommended Citation}

Harris, L., Castro-Lopez, V. and Killard, T. J. (2013) Coagulation monitoring devices: Past, present, and future at the point of care. ,Trends in Analytical Chemistry, Vol. 50, October 2013. doi:/10.1016/ j.trac.2013.05.009

This Article is brought to you for free and open access by the School of Biological Sciences at ARROW@TU Dublin. It has been accepted for inclusion in Articles by an authorized administrator of ARROW@TU Dublin. For more information, please contact arrow.admin@tudublin.ie, aisling.coyne@tudublin.ie,gerard.connolly@tudublin.ie. Funder: Enterprise Ireland

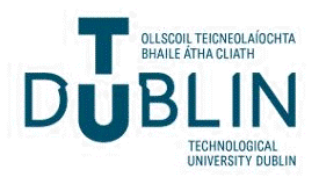


COAGULATION MONITORING DEVICES: PAST, PRESENT, AND FUTURE AT THE POINT OF CARE

\author{
Leanne F. Harris, ${ }^{\text {a* }}$ Vanessa Castro-López, ${ }^{b^{*}}$ and Anthony J. Killard ${ }^{\text {ac,d }}$ \\ * Joint first authors
}

${ }^{a}$ Biomedical Diagnostics Institute, National Centre for Sensor Research, Dublin City University, Dublin 9, Ireland.

${ }^{\mathrm{b}} \mathrm{CIC}$ microGUNE, Goiru kalea 9, Polo Innovación Garaia, 20500, Arrasate-Mondragón, Spain.

${ }^{c}$ Department of Applied Sciences, University of the West of England, Coldharbour Lane, Bristol BS16 1QY, UK.

${ }^{\mathrm{d}}$ Corresponding Author: Prof. Anthony J. Killard.

Department of Applied Sciences, University of the West of England, Coldharbour Lane, Bristol BS16 1QY, UK.

Tel: + 00441173282967

Fax: + 00441173282904

E-mail: tony.killard@uwe.ac.uk 


\begin{abstract}
Automated technologies have revolutionised the monitoring of coagulation disorders in the central hospital laboratory setting, allowing for high throughput testing, improved accuracy and precision, accompanied by a marked reduction in human error. However, they still require trained operators and sample transportation. With the advent of point of care (POC) testing, the working principle of traditional coagulometers was used as the foundation for the development of miniaturised devices. A number of POC coagulation devices have been commercially available for many years now, allowing the patient to assume more control over the management of their own medication, e.g. warfarin. While POC devices for measuring anticoagulation have relied principally on clotting time tests, novel platelet function tests, and factor-specific assays based on enzymatic or immunoassay principles are becoming available, driven by the emergence of new anticoagulant drugs, in addition to the inability of clotting tests to accurately detect many thrombotic disorders. This review highlights recent progress in the development of POC coagulation monitoring technologies and examines their future potential in clinical diagnostics.
\end{abstract}

Keywords: Anticoagulant; blood; coagulation; clotting time; device; point of care. 


\section{The development of central laboratory coagulation testing}

The monitoring of bleeding disorders has been in existence for around 3000 years with the first bleeding time test described by the Chinese emperor Huang $\mathrm{Ti}$, as the length of time that blood flows from the skin after rupture. The bleeding time was also described by Sydenham at the turn of the $17^{\text {th }}$ century, but it was not until the 1900 s when disorders of the clotting system were detected using bleeding time at the bedside [1].

While comparatively more sophisticated in their mode of operation, many coagulation tests still use the same principles since their discovery in the early $19^{\text {th }}$ century, where it was found that blood coming into contact with glass containers or various biological tissues such as placenta accelerated its clotting [1,2]. The development of the understanding of the coagulation cascade and the interaction of various factors led to the development of the first clotting time tests (Fig. 1). These tests now principally include the Prothrombin Time (PT) test, which measures the tissue factor-induced clotting time of plasma [3], the activated Partial Thromboplastin Time (aPTT), one of the most frequently requested screening tests for monitoring unfractionated heparin (UFH) therapy [4, 5], the Activated Clotting Time (ACT), currently used to monitor anticoagulation in patients undergoing cardiopulmonary bypass (CPB) and are receiving high doses of UFH [5], and the Thrombin Time test (TT), a simple assay measuring the conversion rate of fibrinogen to insoluble fibrin after the addition of thrombin to plasma [6]. Changes from the normal clotting times of these assays may result from changes in active coagulation factor concentrations due to genetic factors, disease or injury, or through the administration of anticoagulant drugs.

Initially, assay methods were based on the visual detection of a clot, either through observation of fibrin strands, or detection of bulk changes in viscosity [2,3,7] (Fig. 2). The level of automation involved was typically around controlling the mixing and interaction of the sample with the clotting reagents or surface contact with glass. Progressively, visual detection of clot formation was replaced by optical detection technologies, using turbidimetric [1] and nephelometric [8] techniques in which the change in optical density of the sample resulted from the formation of the fibrin network. Mechanical detection also replaced visual detection in which the change in viscosity was detected, for instance by the cessation of the movement of a steel ball in the rotating sample tube which could be detected optically [9]. This level of automation led to many advantages over manual testing, such as 
high volume testing, better reproducibility due to strict quality control programs, increased user flexibility, and cost reductions.

Coagulation instruments based on optical detection of clot formation could also be made compatible with the need for other assays applicable to haemostasis. This was particularly useful for the measurement of the activity of coagulation factors. These factors are typically serine protease enzymes that transform an inactive zymogen into its active form. The development of chromogenic substrates that, when cleaved would release a chromophore now allowed enzymatic factor assays to be performed alongside traditional coagulation tests on a single instrument platform [10]. Other systems developed modified latex agglutination assays to perform immunoassays, again exploiting principles such as turbidimetry $[11,12]$. This has been further refined through the use of particle proximity assays in which the close proximity of two particles due to a binding interaction, results in a signal from one of the particles. For example, in the Luminescent Oxygen Channelling Immunoassay (LOCI) the photoactivated formation of short-lived singlet oxygen on one particle is then capable of inducing chemiluminescence on a neighbouring particle when bound together via an antibody-antigen interaction [13]. A number of popular commercial central hospital coagulometers and their characteristics are listed in Table 1.

\section{The development of point of care coagulation testing}

The need for point of care (POC) coagulation technologies became necessary as centralized laboratories became increasingly unable to provide results in the time frames required to allow rapid turnaround which would allow timely intervention of anticoagulant therapy [14]. This was equally so for inpatients requiring dosage adjustment during emergency procedures or for outpatients to allow dosage adjustment before leaving the clinic. Such improvements were thus necessary to improve patient satisfaction and improve clinical outcome [5].

While the initial costs of POC testing may be greater, the wider patient, economic, and societal benefits offered by the implementation of such programs cannot be ignored. In a recent review [15], the effects of POC coagulation testing on the rate of perioperative transfusion of allogenic blood products, the frequency of hemostatic treatment, and the clinical outcome were assessed. While POC treatment is limited, the implementation of such programs may potentially reduce rates of transfusion and lower costs associated with 
hemotherapy. Lee-Lewandrowski et al. [16] looked at the impact of a POC testing program in a large academic medical centre where over 500,000 tests are performed annually, ranging from glucose and creatinine testing, to ACT and D-dimer analysis. According to their report, the majority of POC tests was actually performed to improve clinical operations and to aid in capacity management of the hospital facilities, and not out of medical necessity. Thus, improvements were observed in clinical operations rather than clinical outcomes. A similar trend was observed with studies for cardiac markers in emergency department settings, where the length of stay for patients was significantly reduced but with little improvement in clinical outcome [17]. Nichols et al. [18] monitored the clinical outcomes of POC testing in the cardiology setting, and while rapid results were achieved, the impact on patient care was not obvious.

Goodnough \& Hill [19] have highlighted the need for POC coagulation testing in clinical settings including liver transplantation, cardiothoracic surgery, and trauma because of the high risk of hemorrhage and the resulting requirements for blood component support. Other research has identified that POC testing in the form of platelet count, PT, aPTT and fibrinogen concentration has resulted in reduced blood loss, shorter surgical times, and reduced transfusion requirements [20,21]. Asimos et al. [22] conducted a study on trauma patients and determined that taking POC blood measurements such as haemoglobin resulted in reduced morbidity. While clinical outcomes reporting morbidity and mortality indices will give a greater indication of the effectiveness of various POC assays, this data will take a long time to accumulate.

\subsection{POC clotting time tests}

Given the importance of clotting time tests such as PT, aPTT and ACT in the central laboratory setting, these were, unsurprisingly, the first tests to undergo significant development and conversion to POC type platforms [18]. One major driver was the need to have rapid information in the operating theatre on blood coagulation status. The first POC instruments were thus simple, bench top versions of earlier coagulometers, often employing the same principles. For example, the Hemochron ${ }^{\circledR}$ Response system (ITC, USA) employed the Hall effect in which the clotting of the blood sample caused a small magnet to rotate with the sample in the tube, and so changing the magnetic flux of an external electromagnet [23] (Fig. 3a). This is still widely used to perform ACT measurements for high dose heparin 
anticoagulation in major surgeries. The device was gradually equipped with two sample tubes due to the fact that full anticoagulation requires several hundred seconds of measurement time. Thus, assays could be performed alternately to ensure a timely result. The Actalyke® XL and Actalyke ${ }^{\circledR}$ Mini II (Helena Laboratories Point of care, USA) use a related principle of operation in which two magnetic sensors are used to detect the movement of a magnet inserted in the ACT tubes [24]. These two sensors, one at $0^{\circ}$ and the other at $90^{\circ}$, independently sense the magnet in the ACT tube. As the clot begins to form, it displaces the magnet in the test tube. When the magnet reaches a fixed distance between the two detectors (i.e. approximately $46^{\circ}$ away from detector at $0^{\circ}$ ), the system returns the ACT clot time [25].

Until the 1950s, anticoagulant treatment could only be given parenterally in the form of heparin, which limited its use to the hospital setting [26]. The introduction of warfarin as an oral anticoagulant allowed the continuous treatment of those at risk of venous thromboembolism and is still one of the top 40 most prescribed drugs in the USA [27]. However, coumarin has quite unpredictable dose-response characteristics and has a relatively narrow therapeutic window, leaving patients at an elevated risk of bleeding or clotting [28]. This resulted in a major drive to develop devices that could be used in primary care settings such as clinics, by GP surgeries, or even by the patient themselves to allow the more precise control and adjustment of dosage. In the early 1990s a POC device for monitoring warfarin treatment was introduced by Boehringer Mannheim (now part of Roche Diagnostics) called the CoaguChek ${ }^{\circledR}$, which was capable of performing PT measurements. The device used a simple, disposable microfluidic strip in which a whole blood sample taken by fingerstick was combined with a thromboplastin reagent in the presence of small iron filings [29]. These filings could be induced to move by the application of an electromagnetic field and this movement was then detected optically (Fig. 3b). The cessation of movement as a result of coagulation can be detected as the clotting time. This device was also capable of measuring PT using the International Normalized Ratio (INR) which allowed the standardization of PT assays based on World Health Organisation reagents and assay methodologies [30]. Thus, an INR from one device could be reliably compared to the value determined on another. Before the introduction of INR, all PT clotting times were specific for the reagents and test device used. This is still the case, however, for other coagulation tests such as aPTT, for which no international standard has been established. 
Other POC devices for PT/INR have persisted with the mechanical approach to clot formation. For instance, The Coag-Sense ${ }^{\mathrm{TM}}$ PT/INR monitoring system (CoaguSense Inc., USA) is based on a test strip with a rotating, spoked wheel that draws the sample into the reaction well. The spokes rotate across the path of an infrared light beam and mixes the liquid sample with recombinant rabbit thromboplastin which is dried in the reaction chamber. When the sample clots, the spokes simply lift the fibrin clot from the reaction well and the interruption of the light beam is measured by an optical detector. The PT is reported as the time between the introduction of blood onto the test strip and blockage of the light beam in seconds [31]. The manufacturer states that as it is a direct mechanical measurement, results are not affected by low hematocrit levels or by the concentration of blood constituents, resulting in more precise and reliable results [32]. While the assay only requires $10 \mu 1$ of sample, the instrument itself is more bench top than hand-held or portable.

While there are now numerous devices available for self-testing of PT/INR in association with warfarin therapy, other coagulation tests such as aPTT and ACT have remained for professional use only. There are several devices that can perform panels of clotting time measurements in a small, portable device, with accompanying reductions in required sample volumes, materials and reagent costs through the development of disposable polymer chiptype technologies. For example, in the Hemochron® Signature, $15 \mu \mathrm{l}$ of whole or citrated blood is added to a polymer microfluidic test cartridge containing coagulation reagents (Fig. 3c). The sample and reagents are mixed with the aid of pumps within the instrument. This mixing homogenises the sample and reagent and ensures even clotting of the sample. The mixture is then moved back and forward within the channel which is monitored by a series of LEDs. Cessation of movement due to clotting is again detected optically. These devices which again rely on cessation of movement due to clot formation can typically form a panel of assays for PT/INR, aPTT and ACT.

\subsection{POC methods and devices based on thrombin activity}

As was discussed in the context of central hospital laboratory haematology, chromogenic assays have been used to measure the enzymatic activity of specific clotting factors through the development of artificial, cleavable peptide substrates specific for particular factors. It should be noted that assays based on clotting time such as aPTT, PT and ACT are essentially functional measures of thrombin formation and its inhibition in the presence of anticoagulants 
such as warfarin and heparin. Thus, an analogy can be drawn between assays based on the measurement of fibrin formation and assays based directly on the measurement of thrombin activity via the use of appropriate peptide substrates such as in chromogenic assays.

The electrochemical behaviour of blood has been studied since 1928 [33,34]. Electrochemical detection involves the use of a working and a reference electrode, whereby a constant potential is applied to the working electrode leading to an oxidation-reduction reaction that can be quantified as a recordable electric current $[35,36]$. Electrochemical sensors have found widespread use in the development of POC and self-test devices, as exemplified by the development of glucose test strips as they are simple to interface with electronic instruments and reduce device costs. Devices such as the CoaguChek ${ }^{\circledR}$ XS (Roche Diagnostics) and the iSTAT ${ }^{\circledR}$ (Abbott Diagnostics) have both employed electrogenic substrates which result in the formation of an electrochemically detectable cleavage product which is proportional to thrombin activity. These devices then return a clotting time rather than a measure of thrombin activity to allow comparisons with standard clotting tests. However, while the i-STAT® is targeted at professional use and can perform PT/INR and ACT, the CoaguChek $®$ is targeted at the self-test market for PT/INR (Fig. 4a).

INR values of 52 patients receiving oral warfarin were measured using the i-STAT® PT/INR and the CoaguChek ${ }^{\circledR}$ XS Plus and compared with those obtained using the reference laboratory instrument from Diagnostica-Stago (France). Considering the results obtained, INR measurements generated using the CoaguChek® XS Plus correlated better with the Stago system than the results generated using the i-STAT® PT/INR [37]. However in a more recent study, Challen et al. [38] evaluated the impact that close monitoring using the iSTAT® had on outcomes of patients on anticoagulant treatment. Their positive results showed that implementation of the i-STAT® POC machine in a pharmacist-managed anticoagulation clinic increased the proportion of time within therapeutic INR range by $9.9 \%$. In addition, safety, adherence and cost were improved, indicating potential for implementation on a larger scale in the future.

As well as devices that use electrochemical analogies to available chromogenic tests such as the iSTAT ${ }^{\circledR}$ and the CoaguChek ${ }^{\circledR}$ XS, some have attempted other direct means of electrochemical measurement. In some cases, the change in the steady state current is related to a change in sample viscosity [39] and in others, the cleavage of an amperogenic substrate 
leads to an electric current flow which can, for example, relate to thrombin generation [36]. One of the advantages of electrochemical detection is that sample colour/turbidity and the presence of clots or platelets do not affect the measurement [36].

The Alere (formerly HemoSense) INRatio® is a disposable polymer strip with screen printed silver paste electrodes in combination with PT assay reagents [40]. Application of the whole blood to the strip and activation of coagulation is monitored using electrochemical impedance. This technique is sensitive to a number of physical and chemical characteristics of the sample. Electrochemical impedance measures both capacitive and resistive characteristics of the material in contact with the electrode. Blood is a complex mixture of ionic species, insulating biomolecules and interfaces such as membranes which all contribute to its electrochemical impedance properties. In addition, these characteristics also change over time due to the movement of cellular species, formation of the fibrin network and the trapping of cells, platelets and plasma within this matrix. As a result, changes in the resistance of the coagulating blood can be detected which can be related to the clotting time. The INRatio® is also currently used for self-test measurement of PT/INR (Fig. 4b).

Most POC tests for measuring thrombin activity have been based on in vitro methods. However, in vivo methods for thrombin measurement have the potential to yield further information as to its role at the vascular level. Campbell et al. [41] employed laser scanning confocal microscopy (LSCM) to observe in situ thrombin generation, where it has been seen to form a fibrin network more rapidly, densely and in a manner more resistant to lysis than in vitro. Such knowledge can be used to determine targets for anticoagulant therapy, which can either prevent thrombosis or stabilize fibrin clots, thus preventing embolism. The role of thrombin in atherosclerosis has also been studied using intracellular fluorescent probes of thrombin activity used in combination with in vivo fluorescence imaging [42]. Other in vivo studies of thrombin have employed microenzyme immunoassay to measure thrombinantithrombin complex (TATc) levels, and correlated these against images of atherosclerotic plaques using non-invasive computed tomographic angiography [43]. Such studies have indicated that in vivo thrombin generation is independently related to the occurrence and severity of coronary artery disease. 


\subsection{Immunoassays for POC coagulation testing}

While other assay types such as chromogenic and immunoassay were readily integrated into laboratory-based coagulometers, development of such assays in the POC sector has been principally through stand alone platforms for a number of critical analytes. One of the key analytes is D-dimer which is used to diagnose thrombosis or disseminated intravascular coagulation (DIC) [44]. D-dimer is formed as a result of the breakdown of a clot following fibrinolysis and is typically measured using immunoassay. The Triage ${ }^{\circledR}$ system (Alere, USA) uses a microfluidic cartridge with capillary structures to meter the volumes of blood used in the assay, and a series of reaction areas in which the sample mixes with immobilised reagents for defined time periods. Here, the D-dimer binds to a labelled antibody which is in turn captured at a capture site downstream forming a coloured line. The Triage ${ }^{\circledR}$ is an example of a lateral-flow type immunoassay converted to a polymer microfluidic platform. In a study on a number of POC D-dimer assay platforms, Geersing et al. [45] showed that while there were variations in their ease of use all platforms exhibited comparable accuracy.

While clotting factor deficiencies have traditionally been diagnosed using conventional clotting assays, immunological tests are more suited to the study of hereditary thrombotic states or predisposition such as protein $\mathrm{C}$, protein $\mathrm{S}$, antithrombin and tests for evidence of DIC including fibrinogen degradation products (FDPs), fibrinogen, and D-dimers [46]. Most POC devices use antibody-antigen binding technologies as they allow for assay specificity and sensitivity and are versatile in the detection methodology that can be used such as fluorescence, time resolved fluorescence or turbidimetry [47]. On the other hand, immunoassays are often time consuming and depending on the specificity of the assay, the antibodies of choice can be expensive. Sensors based on immunoassays often have difficulty competing with traditional immunoassays which typically demonstrate greater sensitivity. However, they do hold promise for testing where sensitivity can be sacrificed for improved ease of use and faster time to result, such as in near-patient setting [48].

\subsection{Resonant transducers}

What is clear from the earlier discussion is that a large number of coagulation tests have exploited the change in viscosity that results from clot formation. Initially, this was achieved using slow, bulk methodologies. However, the tilt tube test introduced an important principle 
which has been further refined and applied to coagulation testing, which is the application of an oscillatory force to the system. This was enhanced in other devices such as the Hemochron ${ }^{\circledR}$ Signature in which the sample was pumped backwards and forwards to enhance and detect clotting. In an extension of what is essentially a form of oscillatory rheometry, other systems such as the Thromboelastograph ${ }^{\circledR}($ TEG®, Hemonetics Corp.) and ROTEM ${ }^{\circledR}$ (Tem International, $\mathrm{GmbH}$ ) have used the application of an oscillating sheer force to measure the resulting sheer stress in a time-dependent manner during coagulation $[2,49]$. These technologies have found favour particularly among anaesthesiologists as they provide complex but detailed information on patient clotting status and fibrinolysis. For instance, TEG ${ }^{\circledR}$ traces can show clotting times, rates of clot formation, and overall clot strength. These parameters contain vital information as to levels of clotting factors, platelets, and fibrinogen concentration. However, due their size and complexity, oscillatory rheometry has not transitioned into wider POC application and acceptance.

Several miniaturized resonant transducer systems have been applied to blood coagulation measurement. Devices such as the quartz crystal resonators are also sensitive to changes in viscosity of a material in contact with its surface. These devices typically operate at high frequencies (10-20 MHz) and their penetration depth into the sample is only on the order of 100-200 nm. They have been extensively investigated for their ability to monitor blood coagulation. However, the cost of quartz crystal resonators makes it prohibitive as a single use disposable device, while re-use is made challenging as biomaterials such as fibrin adhere extremely well to the gold electrode surface and are very difficult to regenerate effectively. Others are now employing alternative microresonators based on MEMS technologies. One such system is the disposable SmartStrip ${ }^{\circledR}$ developed by Microvisk Technologies Ltd (UK) [50]. Microvisk uses MEMS blood sensors on a disposable strip, which incorporates two microcantilevers to measure changes in viscosity of the blood over time. One measures blood thickness, while the other one detects background vibrations that are subtracted to provide a better signal. The cantilevers are comprised of several layers of materials: plastic (two polyamide strips), heaters and sensors (piezo-resistive element). The heater and the piezoresistive element are located between the two polyamide layers which have different coefficients of expansion. With an increase in temperature, the cantilevers vibrate while the piezoelectric generates a small current that indicates how much they flex. When a drop of whole blood taken by a finger prick reacts with the dried thromboplastin stored on the strip, the blood starts to coagulate. This change in viscosity is sensed by the cantilevers and 
transmitted to the piezo-resistive layer indicating the coagulation endpoint [50-52]. These devices can be mass-manufactured at low cost, which is an essential requirement for single use disposability.

Table 2 summarizes the characteristics of 23 commercially available POC coagulation analyzers $[5,14,25,53,54,55]$.

\subsection{POC tests for platelet function}

With the increase in understanding of the role played by platelets in arterial thrombosis, growing numbers of patients are being treated with platelet inhibitors (e.g., aspirin) and other non-steroidal anti-inflammatory drugs, thienopyridine derivatives (e.g. ticlodipine, clopidogrel) and GP IIb/IIIa receptor antagonists (e.g. tirofiban, Abciximab) [54,56]. Treatment with these antiplatelet drugs has enhanced the need to monitor their effects in order to avoid bleeding and thrombosis. Platelet testing was traditionally based on platelet aggregometry. However, such tests do not represent physiological conditions [57,58]. Several novel platelet function tests have been developed to assess platelet function and the impact of antiplatelet therapies at the POC $[5,25,53,57]$ (Table 3). One of these, the VerifyNow® (Accumetrics, USA) is essentially a form of miniaturised light transmission aggregometry performed in a disposable cartridge. The level of aggregation is sensitive to a number of antiplatelet therapies [59]. However, such devices again do not fully take into consideration the complex nature of platelets and their interactions with soluble clotting factors, surfaces and each other [60], resulting in the lack of test standardization in the assessment of antiplatelet therapy $[54,61]$.

\section{Future perspectives}

While there have been many technological advances in coagulation testing in the last one hundred years or so, many technologies are still measuring changes in bulk viscosity, or use other relatively simple principles such as enzyme activity or particle aggregation. However, the drive for POC has also driven technological solutions which can operate at the microscale and many such innovations have been implemented in the available commercial technologies. 
While there is quite an array of devices for performing clotting time tests, there still remains the need to improve and refine the way clotting end points are determined. Table 4 outlines a selection of novel technologies from the research literature [36,62-68]. At present, the clotting time is a relatively arbitrary point at which the burst in thrombin production leads to an exponential rise in fibrin formation. It is this rapid change that is assigned as the clotting time. However, the precise onset of this process is highly unpredictable. In a large, bulk sample, initiation of coagulation processes may take place at different times and different locations, leading to an inherent imprecision in the derived clotting time value. The ACT test for example, has been shown to be highly variable for use in patients undergoing cardiopulmonary bypass in instances of hypothermia and haemodilution, resulting in the unreliable assessment of anticoagulation [69]. Dudek et al. [63] developed a microstructured microfluidic device for performing an aPTT assay that analysed clot formation at the microscopic level using a fluorescent fibrinogen label. They found that clotting time could be determined by monitoring the distribution of clot formation using the fluorescence generated from the incorporated labelled fibrin. This led to very precise measurement of clotting time, as well as a much wider dynamic range for heparin measurement beyond the range typically used in conjunction with aPTT and normally requiring ACT.

There is also a demand for novel POC assays for haemostasis. Some of this relates to the fact that many standard tests have not yet translated into POC formats such as routine tests for thromboembolic complications that can detect factor V Leiden, lupus anticoagulant, protein $\mathrm{C}$, protein S, and AT deficiency [70]. There is also a gradual move away from traditional anticoagulant drugs such as warfarin and heparin due to their unpredictable pharmacokinetic properties. This presents two challenges for coagulation testing. The first is whether there will be a continuing need to monitor the effects of these new drugs, given their much improved and more predictable characteristics and, the second is how they can be tested if this is necessary. Already, clinical guidelines of the monitoring of novel anticoagulant therapies are demonstrating that while the requirement for testing may be reduced, it will still be necessary for atypical patients such as pregnant women, children, under- and overweight people and people with renal dysfunction. In addition, low molecular weight heparins cannot be effectively monitored using current clotting time tests as these are predominantly based on thrombin formation. Low molecular weight heparins have far less impact on thrombin, but exert their control in the preceding step in the coagulation cascade where they primarily inhibit Factor Xa activity. Thus, tests for Factor $\mathrm{Xa}$ at the point of care may become 
increasingly important. A novel fluorogenic anti-FXa assay was developed for monitoring low molecular weight heparins by Harris et al. [71]. The assay was further developed and modified and the ability to measure the concentration of both unfractionated and low molecular weight heparin anticoagulant drugs in plasma was demonstrated using a polymer microfluidic device (unpublished data).

As with the emergence of the laboratory-based coagulometers, the ability to perform multiple assay types on a single platform is also an increasing driver for POC devices. This means that, where possible, the assays must share a common transduction mechanism. For example, Aizawa et al. [72] developed an immunosensor for measuring fibrinogen and fibrindegradation products based on quartz crystal resonator employing a latex agglutination assay. In the presence of fibrin degradation products and latex beads with immobilised antibodies, agglutination at the surface of the quartz crystal brought about a measurable change in resonant frequency. Such an assay could share a common microresonator platform with clotbased assays using a commercially viable MEMS-based technology.

While attempts to improve POC testing are currently focussed on the development of lowcost miniaturised devices [73], Giljohann and Mirkin [74] suggested that new materials such as nanostructures, present attractive properties for the development of miniaturized biodevices such as controllable size-dependent properties, adaptable chemical composition, and chemically and physically robust structures. Polyvalent nanoparticles, carbon nanotubes, and silicon nanowires are all materials that can allow for the easy translation of a change in electrical conductance due to target binding, into a spectroscopic or electrical signal. Nanoshells and noble-metal nanoparticles can be modified to recognise biomolecules so that they can detect proteins, elemental ions, and small molecules. Such strategies allow adaptation for many analyte types and due to the properties of nanostructures, they can be easily manipulated providing excellent versatility and increased sensitivity. Label-free technologies such as the microsphere resonator biosensor for thrombin measurement as developed by Zhu et al. [75] highlight another area of biosensor development that will allow for high sensitivity and selectivity with a wide range of biomolecules. 


\section{Conclusions}

In the one hundred years since the first clotting time tests were proposed, the development of coagulation assay technology has progressed significantly to a point where it now allows individuals to assess their own clotting status in the comfort of their own homes. The range and the quality of the tests available has also increased significantly, allowing various measures of clotting time, platelet function, factor activity, and concentration. These tests have progressed alongside an increased understanding of the processes involved in haemostasis and the development of anticoagulant drug therapies. Many of these tests are still only relevant to professional use applications. Only in the case of PT/INR has coagulation testing emerged as a consumer diagnostic product. Nonetheless, many POC platforms now exist to facilitate the rapid and convenient measurement of clotting status in all clinical scenarios including operating theatres, emergency rooms, in-patient and out-patient settings, in the management of a wide range of conditions from the diagnosis of genetic coagulation disorders, management of perioperative anticoagulation, in the treatment of thrombosis, and for the prophylactic management of a wide range of thrombophilic conditions.

Many new technologies continue to be applied to enhance and refine the ability to perform coagulation tests at the POC, primarily focussed on improved systems miniaturisation and functional integration. While the technologies being used may be ingenious, the adoption of such devices is not without many significant challenges which include the quality, robustness and cost of the underlying technology, intellectual property issues, regulatory approval, clinical acceptance, the economics of test usage and the ultimate market size. It is not surprising then, that much technological development has been predominantly incremental in nature. Coagulation testing is also under pressure from improvements in drug treatment that claim to not require monitoring. While this may be partially true, the cost and rate of adoption of new drugs, coupled to the complexities involved in managing patients with very specific medical requirements will ensure that some amount of testing will remain for some time to come and that new tests for new drugs may open up new testing opportunities. Certainly the challenge of the management of the aging population may also see a continued demand for devices suitable for out-patient and self-test use in an attempt to contain ever-increasing healthcare spending. It is assumed that further technological development will continue to make these cheaper, quicker and simpler to use. 


\section{Acknowledgements}

This work was supported by Enterprise Ireland under Grant No. TD/2009/0124. 


\section{References}

[1] M.H. Qari, Combi. Chem. High Throughput Screen. 8 (2005) 353.

[2] G. Lippi, E.J. Favalaro, M. Franchini, G.C. Guidi, Semin. Thromb. Haemost. 35 (2009) 9.

[3] A.J. Quick, M. Stanleybrown, F.W. Bancroft, Am. J. Med. Sci., 190 (1935) 501.

[4] S.M. Bates, J.I. Weitz, Circulation 112 (2005) 53.

[5] D.J. Perry, D.A. Fitzmaurice, S. Kitchen, I.J. Mackie, S. Mallett, Br. J. Haematol. 150 (2010) 501.

[6] S. Kitchen, M. Makris, in: D. O’Shaughnessy, M. Makris, D. Lillicrap (Eds.), Practical Hemostasis and Thrombosis, Blackwell Publishing, Massachusetts, 2005, p. 8.

[7] M. Heins, H. Reinauer, J. Int. Fed. Clin. Chem. 8 (1996) 117.

[8] B.F. Rodak, G.A. Fritsma, K. Doig, Hematology: Clinical Principles and Applications, third ed., Elsevier Saunders, Missouri, 2007.

[9] S. Kitchen, A. McCraw, M. Echenagucia, Diagnosis of Hemophilia and other Bleeding Disorders: A laboratory manual, World Federation of Hemophilia, Montréal, 2010.

[10] S. Rosen, Hamostaseologie, 25 (2005) 259.

[11] E.F. Ullman, H. Kirakossian, S. Singh, Z.P. Wu, B.R. Irvin, J.S. Pease, A.C. Switchenko, J.D. Irvine, A. Dafforn, C.N. Skold, D.B. Wagner, Proc. Natl. Acad. Sci. USA 91 (1994) 5426.

[12] E.F. Ullman, H. Kirakossian, A.C. Switchenko, J. Ishkanian, M. Ericson, C.A. Wartchow, M. Pirio, J. Pease, B.R. Irvin, S. Singh, R. Singh, R. Patel, A. Dafforn, D. Davalian, C. Skold, N. Kurn, D.B. Wagner, Clin. Chem. 42 (1996) 1518.

[13] A. Kappel, M. Ehm, Hamostaseologie 30 (2010) 194.

[14] C.E. Dempfle, M. Borggrefe, Semin. Thromb. Hemost. 34 (2008) 445.

[15] C.F. Weber, K. Zacharowski, Dtsch. Arztebl. Int. 109 (2012) 369.

[16] E. Lee-Lewandrowski, K. Gregory, K. Lewandrowski, Clin. Chim. Acta. 411 (2010) 1799.

[17] A.B. Storrow, J.A. Lyon, M.W. Porter, Z. Chuan, H. Jin Ho, C.J. Lindsell, Point of Care 8 (2009) 121.

[18] J.H. Nichols, R.H. Christenson, W. Clarke, A. Gronowski, C.A. Hammett-Stabler, E. Jacobs, S. Kazmierczak, K. Lewandrowski, C. Price, D.B. Sacks, R.L. Sautter, G. Shipp, L. Sokoll, I.D. Watson, W. Winter, M.L. Zucker, Clin. Chim. Acta 379 (2007) 14. 
[19] L.T. Goodnough, C.C. Hill, Transfusion 52 (2012) 56.

[20] G.J. Despotis, S.A. Santoro, E. Spitznagel, K.M. Kater, J.L. Cox, P. Barnes, D.G. Lappas, J. Thorac. Cardiovasc. Surg. 107 (1994) 271.

[21] B.D. Spiess, B.S. Gillies, W. Chandler, E. Verrier, J. Cardiothorac. Vasc. Anesth. 9 (1995) 168.

[22] A.W. Asimos, M.A. Gibbs, J.A. Marx, D.G. Jacobs, R.J. Erwin, H.J. Norton, M. Thomason, J. Trauma 48 (2000) 1101.

[23] R. Lorincz, R. Hall, Solid state apparatus employing Hall effect sensors for detecting the coagulation of blood, Patent No. 6,136,271 (2000).

[24] I.J. Welsby, E. McDonnell, H. El-Moalem, M. Stafford-Smith, J.G. Toffaletti, J. Clin. Monit. Comput. 17 (2002) 287.

[25] D. Prisco, R. Paniccia, Thromb. J. 6 (2003) 1.

[26] T. Baglin, T.W. Barrowcliffe, A. Cohen, M. Greaves, Br. J. Haematol. 133 (2006) 19.

[27] M. Bartholow, Top 200 prescription drugs of 2009, http://www.pharmacytimes.com/publications/issue/2010/May2010/RxFocusTopDrugs-0510, (last accessed 22 ${ }^{\text {nd }}$ April 2013).

[28] S. Middeldorp, Thromb. Res., 122 (2008) 753.

[29] M. Vacas, P.J. Lafuente, I. Unanue, J.A. Iriarte, Haematol. J. 5 (2004) 35.

[30] S. Kitchen, F.E. Preston, Thromb. Haemost. 69 (1993) 1106.

[31] Review Memorandum, Substantial equivalence determination decision summary, http://www.accessdata.fda.gov/cdrh_docs/reviews/K093243.pdf, (last accessed $22^{\text {nd }}$ April 2013).

[32] CoaguSense Inc., CoaguSense self-testing PT monitoring system, Dpeartment of Health, 2010, http://www.coagusense.com/professionals.php, (last accessed 22 ${ }^{\text {nd }}$ April 2013).

[33] H.A. Abramson, J. Exp. Med. 47 (1928) 677.

[34] C.C. Shih, C.M. Shih, Y.Y. Su, L.H.J. Su, M.S. Chang, S.J. Lin, Thromb. Res. 111 (2003) 103.

[35] T. Brock, N. Gentile, R. Louie, L. RF, N. Tran, T. Kitano, G. Kost, Clin. Chem. 55 (2009) 398.

[36] C. Thuerlemann, A. Haeberli, L. Alberio, Clin. Chem. 55 (2009) 505.

[37] M. Donaldson, J. Sullivan, A. Norbeck, Am. J. Health Syst. Pharm. 67 (2010) 1616. 
[38] L.M. Challen, T.G. Nguyen, A. Villalon, Hosp. Pharm. 46 (2011) 105.

[39] M. Teodorczyk, E.J. Kiser, L.P. Olson, D. McAllister, V. V Yuzhakov, K.W. Leong, (2006).

[40] J. Arvind, Coagulation or lysis assays by measuring impedance, Patent No. 6,673,622 (2004).

[41] R.A. Campbell, K.A. Overmyer, C.R. Bagnell, A.S. Wolberg, Arterioscler. Thromb. Vasc. Biol. 28 (2009) 2247.

[42] N.Q. Olson ES, Whitney MA, Friedman B, Aguilera TA, Crisp JL, Baik FM, Jiang T, Baird SM, Tsimikas S, Tsien RY, Integr. Biol. 4 (2012) 595.

[43] J.I. Borissoff, I.A. Joosen, M.O. Versteylen, H.M. Spronk, H. ten Cate, L. Hofstra, Cardiovasc. Imaging 5 (2012) 1201-10.

[44] C. Dempfle, M. Schraml, I. Besenthal, R. Hansen, J. Gehrke, W. Korte, M. Risch, P. Quehenberger, S. Handler, E. Minar, I. Schulz, R. Zerback, Clin. Chim. Acta 307 (2001) 211.

[45] G.-J. Geersing, D.B. Toll, K.J.M. Janssen, R. Oudega, M.J.C. Blikman, R. Wijland, K.M.K. de Vooght, A.W. Hoes, K.G.M. Moons, Clin. Chem. 56 (2010) 1758.

[46] D. Dawson, H. Waters, J. Ardern, in: D. Wild (Eds.), The Immunoassay Handbook, Elsevier Ltd., London, 2005, p. 629.

[47] D.G. Wild, The Immunoassay Handbook, third ed., Elsevier Ltd., London, 2005.

[48] P. D’Orazio, Clin. Chim. Acta 334 (2003) 41.

[49] M.T. Ganter, C.K. Hofer, Anesth. Analg., 106 (2008) 1366.

[50] A. Warner, Microvisk Ltd., Handheld blood coagulation device, Trustech NHS 2012, http://www.trustech.org.uk/case-study/microvisk/, (last accessed $22^{\text {nd }}$ April 2013).

[51] J. Bouchaud, R. Nixon, MEMS sensor determines clots, MEMS Monthly Market Brief, iSuppli Corporation, 3 (2010) 13.

[52] G. Graham-Rowe, A portable cheap blood-clotting test, TEchnology Review 2008, http://www.technologyreview.com/news/411164/a-portable-cheap-blood-clotting-test/, (last accessed 22 ${ }^{\text {nd }}$ April 2013).

[53] T.W. Stief, J. Fareed, Clin. Appl. Thromb. Haemost. 9 (2003) 191.

[54] N.M. Gibbs, Anaesth. Intensive Care, 37 (2009) 354.

[55] CAP Today, Coagulation Analysers - POint of Care Self Monitoring 2011, http://www.cap.org/apps/docs/cap_today/0511/0511_CAPTODAY_CoagAnalyzersPOCselfMonitorGuide.pdf, (last accessed $22^{\text {nd }}$ April 2013). 
[56] A.D. Michelson, Circulation 110 (2004) 489.

[57] A. Calatzis, M. Leitner, S. Panzer, Hamostaseologie 29 (2009) 279.

[58] P. Harrison, Blood Rev. 19 (2005) 111.

[59] A.D. Michelson, Am. J. Cardiol. 103 (2009) 20.

[60] H. Seidel, M.M. Rahman, R.E. Scharf, Hamostaseologie 31 (2011) 41.

[61] J.L. Ferreiro, D. Sibbing, D.J. Angiolillo, Thromb. Haemost. 103 (2010) 1128.

[62] C, De Ribes, P. Eguiguren, Micorfluidic device and method for fluid clotting time determination, Patent No. 2,201,365 B1 (2006).

[63] M.M. Dudek, T.L. Lindahl, A.J. Killard, Anal. Chem. 82 (2010) 2029.

[64] S. Sinn, L. Müller, H. Drechsel, M. Wandel, H. Northoff, G. Ziemer, H.P. Wendel, F.K. Gehring, Analyst 135 (2010) 2930.

[65] Y.H. Tennico, D. Hutanu, M.T. Koesdjojo, C.M. Bartel, V.T. Remcho, Anal. Chem. 82 (2010) 5591.

[66] F.J. Tovar-Lopez, G. Rosengarten, E. Westein, K. Khoshmanesh, S.P. Jackson, A. Mitchell, W.S. Nesbitt, Lab Chip 10 (2010) 291.

[67] M.M. Dudek, N.J. Kent, P. Gu, Z.H. Fan, A.J. Killard, Analyst 136 (2011) 1816.

[68] M. Evander, A.J. Ricco, J. Morser, G.T. a Kovacs, L.L.K. Leung, L. Giovangrandi, Lab Chip, 13 (2013) 722.

[69] L.J. Enriquez, L. Shore-Lesserson, Br. J. Anaesth. 103 (2009) 14.

[70] M. Heins, H. Reinauer, J. Int. Fed. Clin. Chem. 8 (1996) 117.

[71] L.F. Harris, V. Castro-López, N. Hammadi, J.S. O’Donnell, A.J. Killard, Talanta, 81 (2010) 1725.

[72] H. Aizawa, S. Kurosawa, M. Tozuka, J.-W. Park, K. Kobayashi, H. Tanaka, Biosens. Bioelectron. 18 (2003) 765.

[73] M. Bissell, F. Sanfilippo, Trends Biotechnol. 20 (2002) 269.

[74] D. Giljohann, C.A. Mirkin, Nature (2009) 461.

[75] H. Zhu, J.D. Suter, I.M. White, X. Fan, Sensors 6 (2006) 785. 


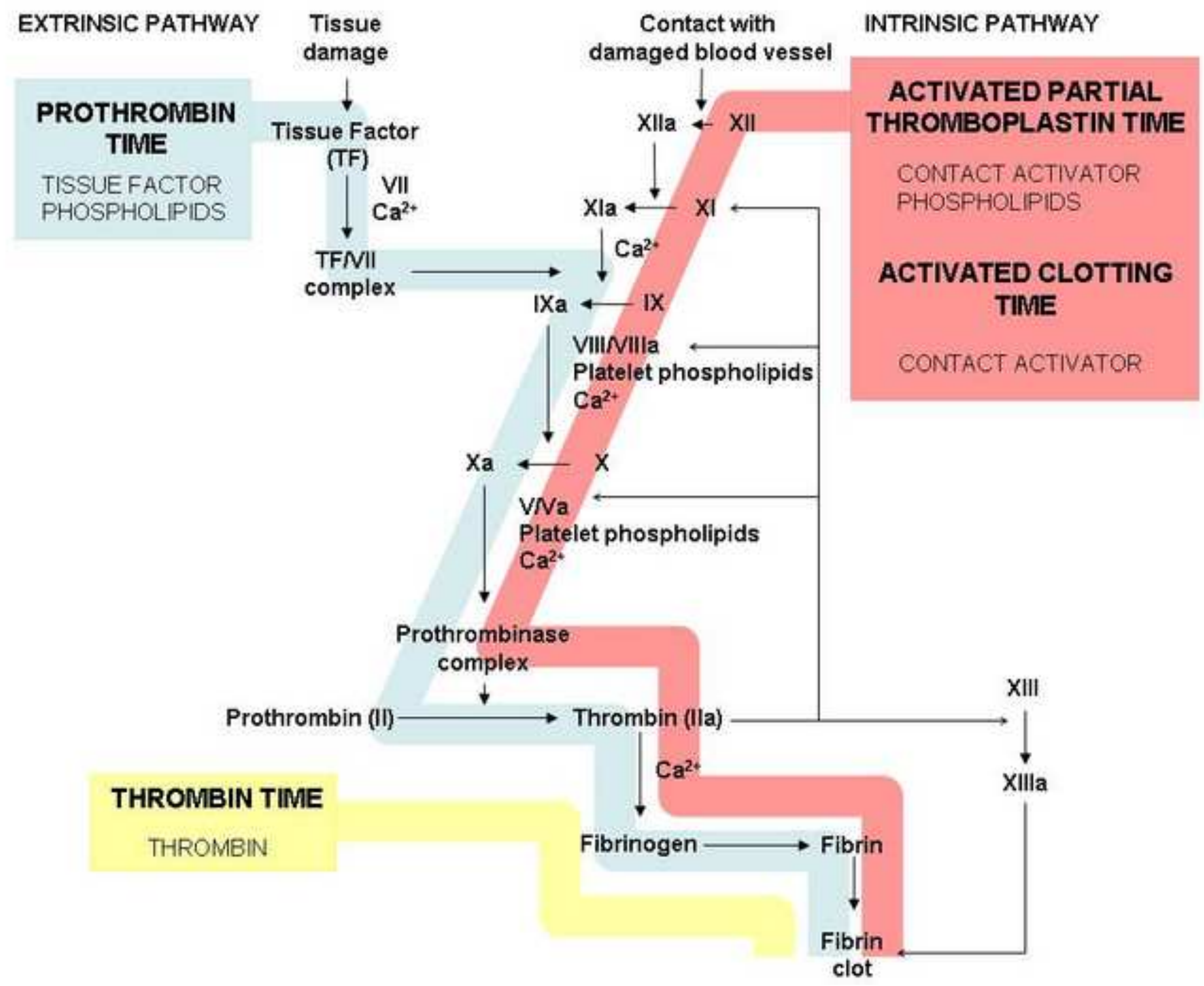


Click here to download high resolution image

(a)

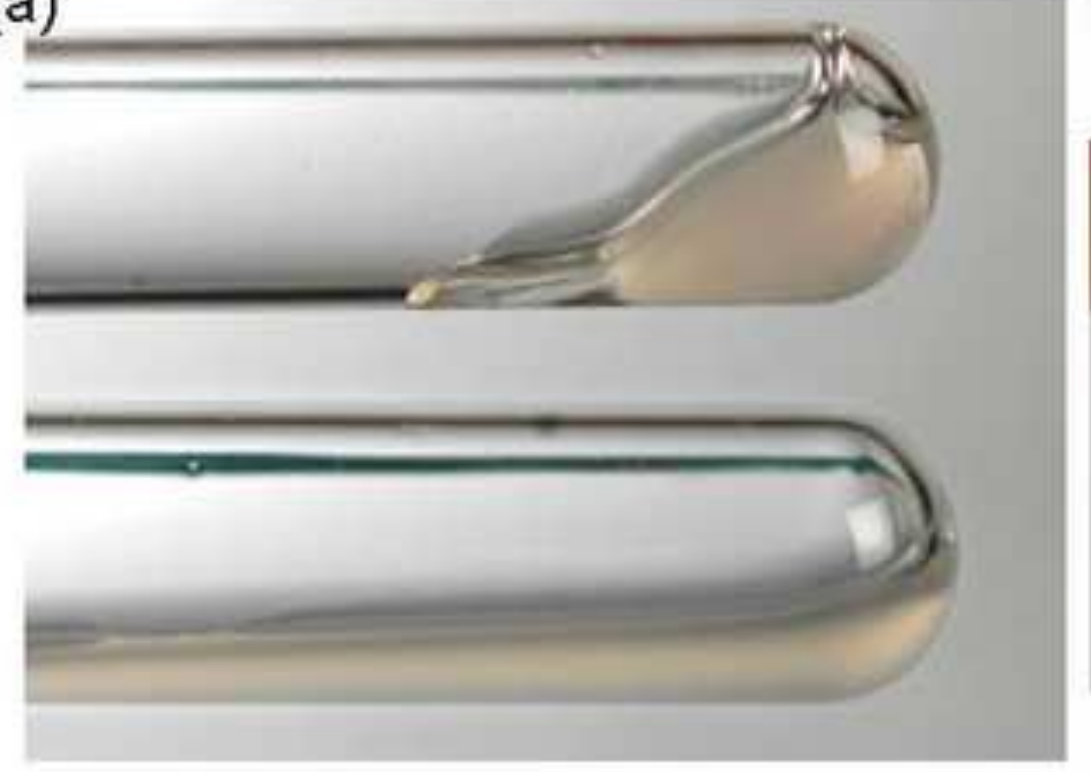

(c)

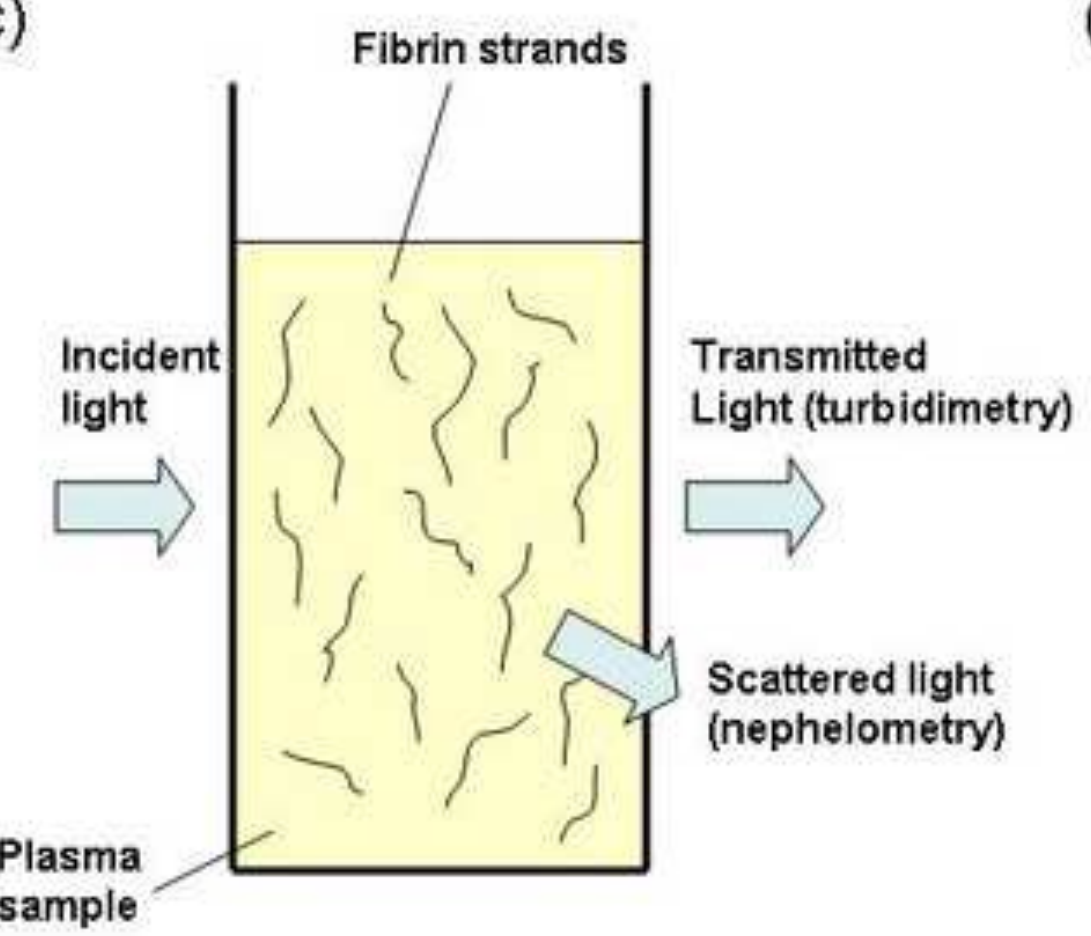

(b)
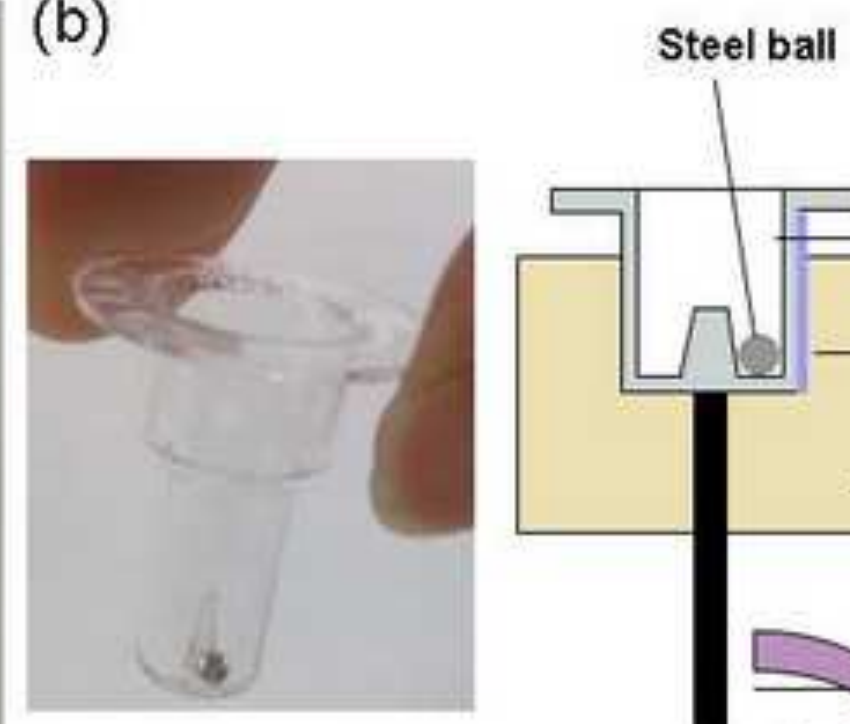

(d)

$$
\begin{aligned}
& \text { Response intensity } \\
& \text { (e.g., scattered light) }
\end{aligned}
$$

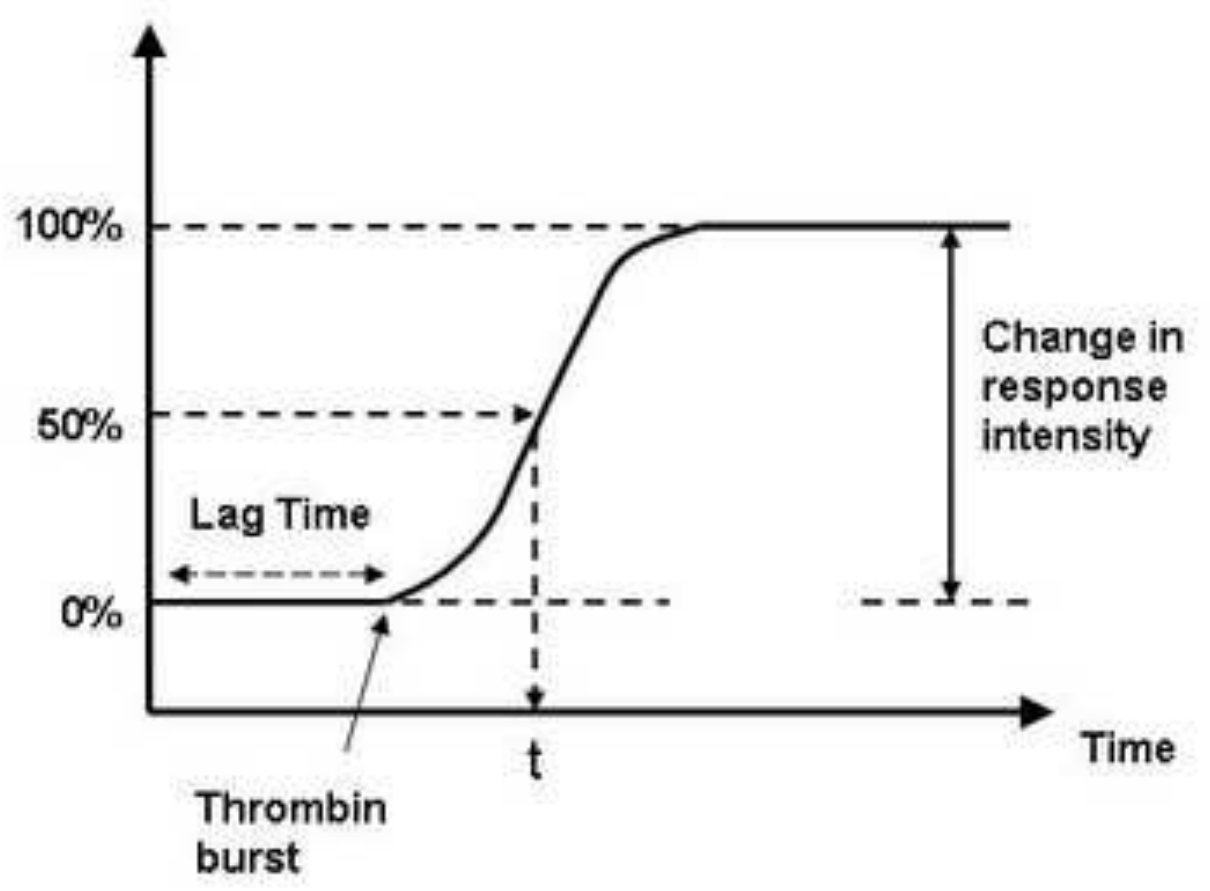


Click here to download high resolution image

(a)

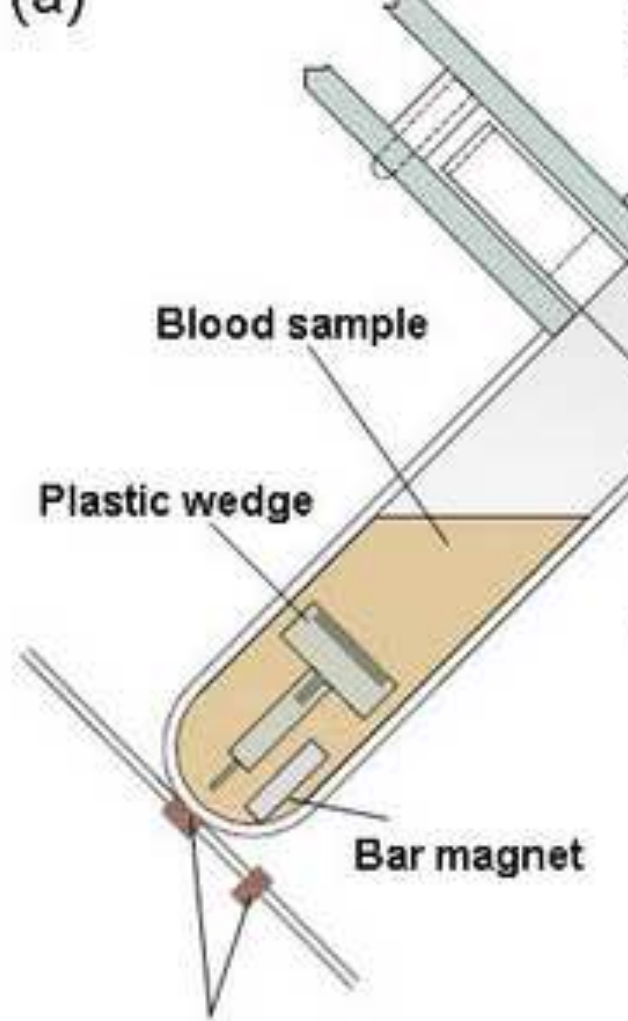

Hall effect sensors
Colour-coded

sample tube

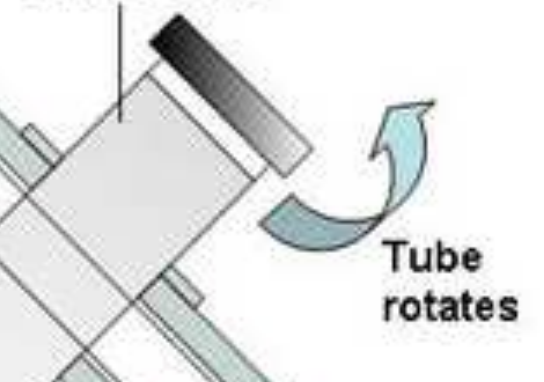

(c)

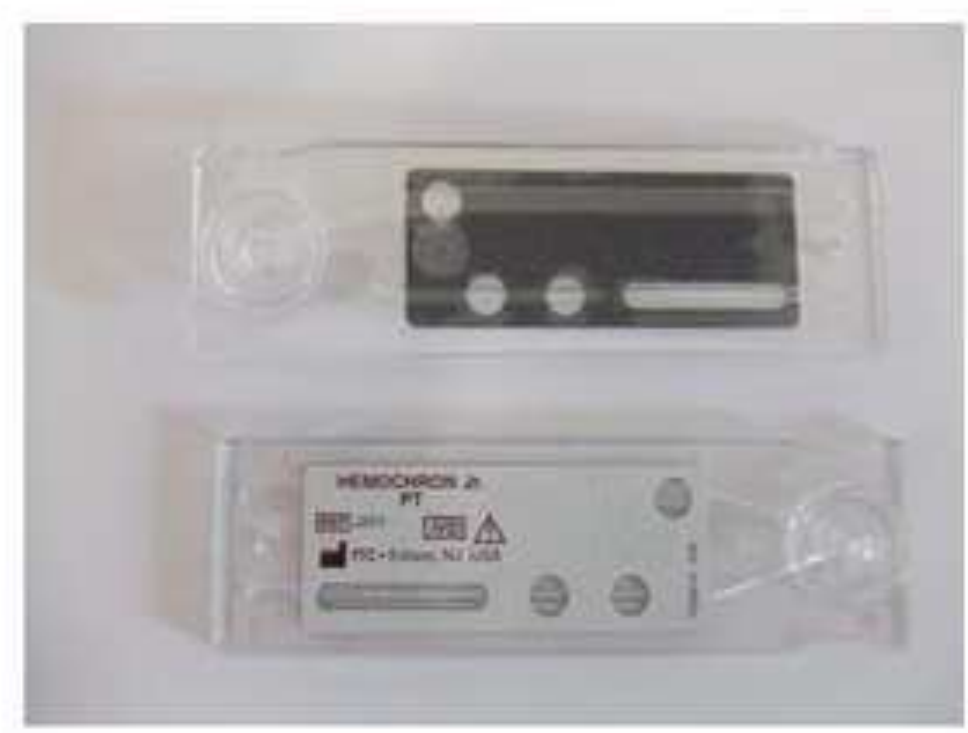

Photodetector

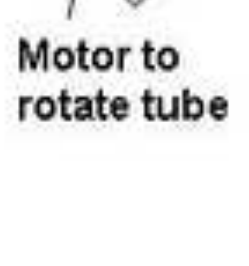

(b)

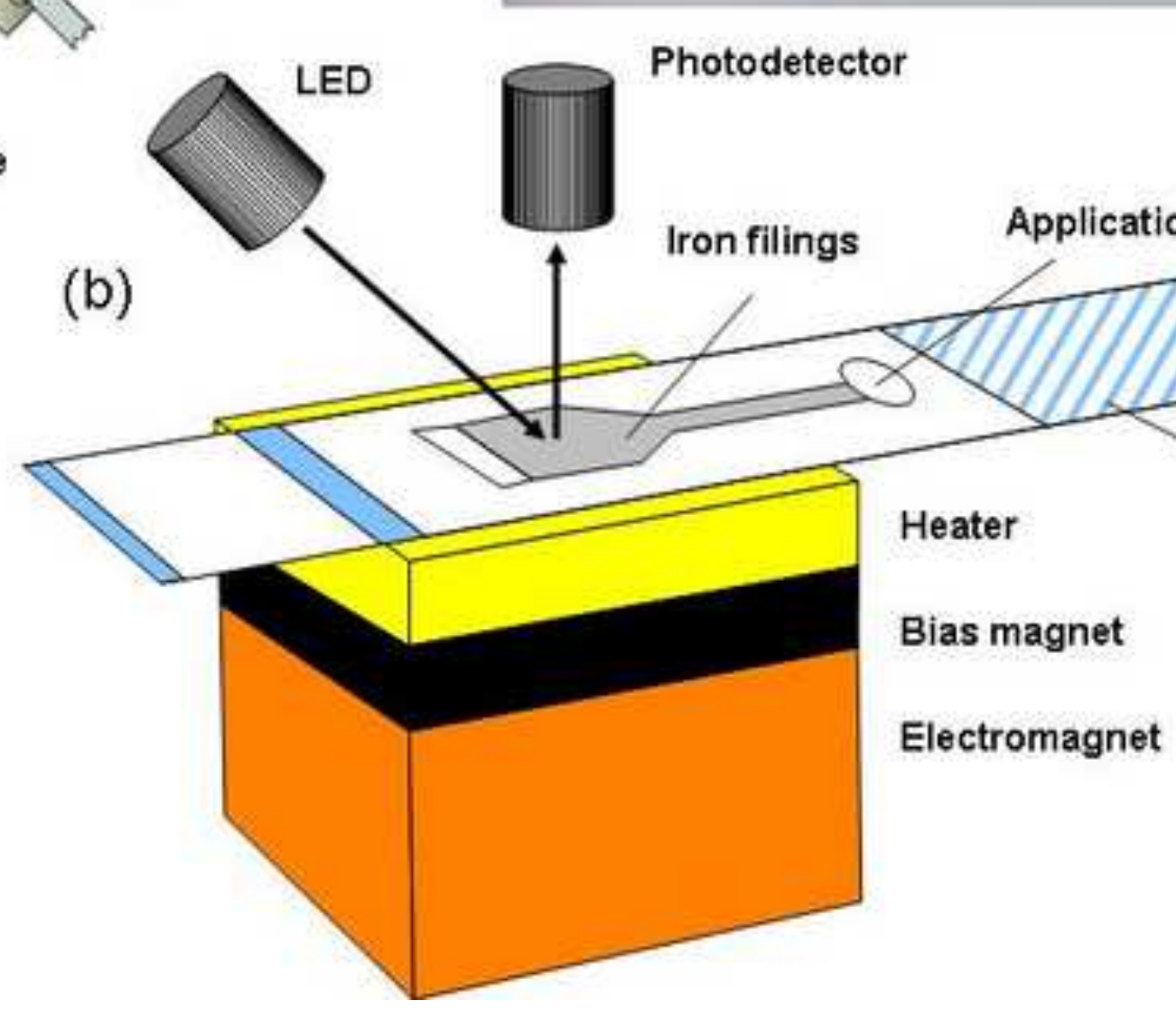




\section{Working \\ Coagulation \\ Drop detect} electrode chemistry electrode

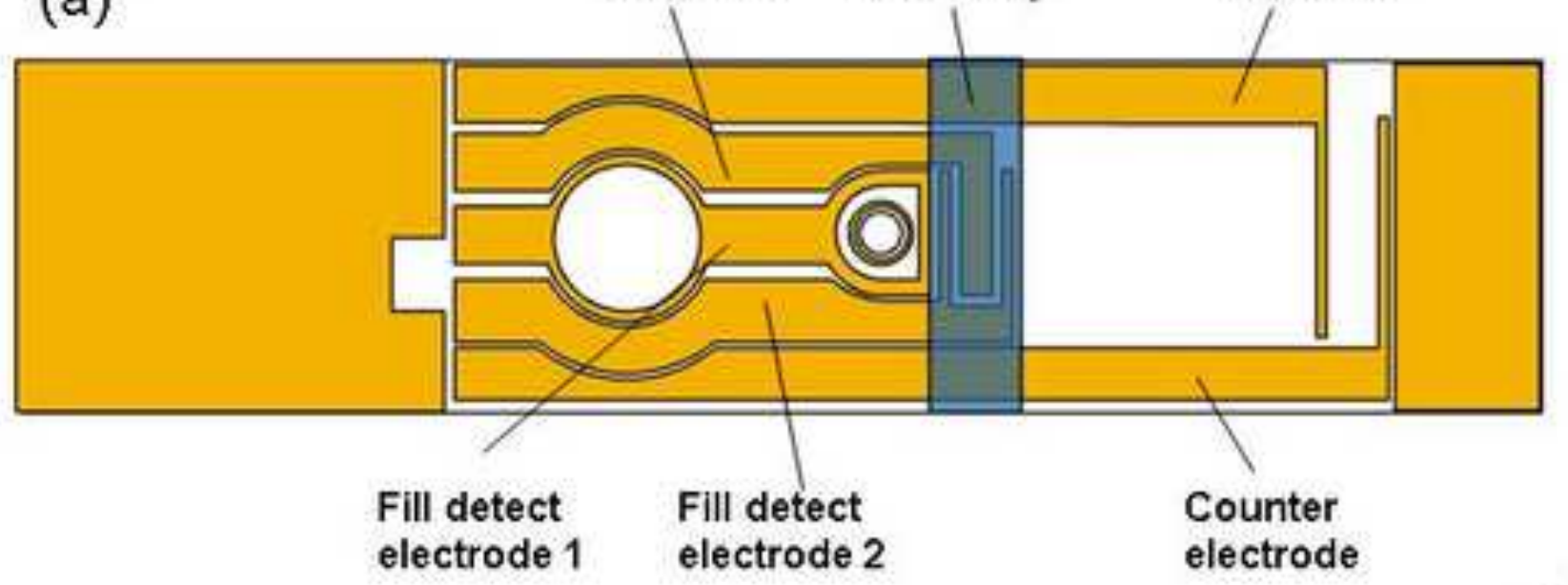

(b)
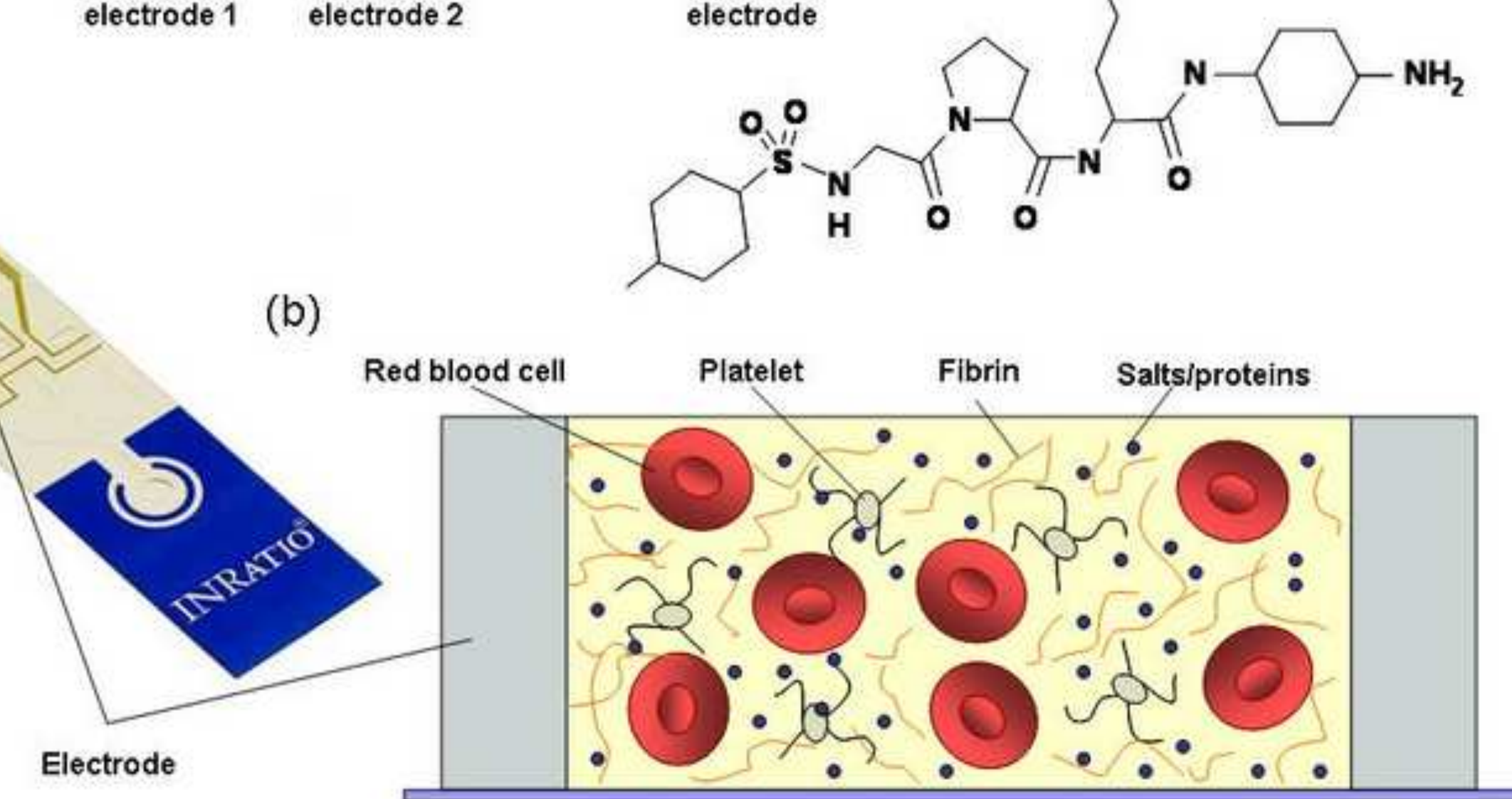


\begin{tabular}{|c|c|c|c|}
\hline Coagulometer & Automation & $\begin{array}{l}\text { Detection } \\
\text { Methodology }\end{array}$ & Assay Menu \\
\hline $\begin{array}{l}\text { BCS® XP; Sysmex® } \\
\text { (Siemens Healthcare } \\
\text { Diagnostics, USA) }\end{array}$ & Full & $\begin{array}{l}\text { Chromogenic } \\
\text { Immunologic } \\
\text { Photo-optical } \\
\text { Turbidimetric }\end{array}$ & $\begin{array}{l}\text { a2-Antiplasmin, Antithrombin, aPTT } \\
\text { TT, Anti-Xa, Fibrinogen } \\
\text { FII;FV;FVII;FVIII;FIX; ,FX; FXI; } \\
\text { FXII, FV-Leidin, LA, Plasminogen, } \\
\text { Protein C, PT, UFH, VWF }\end{array}$ \\
\hline $\begin{array}{l}\text { STA-R® series } \\
\text { (Diagnostica Stago, } \\
\text { France) }\end{array}$ & Full & $\begin{array}{l}\text { Chromogenic } \\
\text { Immunologic } \\
\text { Mechanical }\end{array}$ & $\begin{array}{l}\text { Antiplasmin, TAFI, Antithrombin, } \\
\text { aPTT } \\
\text { TT, UFH \& LMWH, D-dimer, } \\
\text { Fibrin, Fibrinogen, LA, } \\
\text { Microparticles, Plasminogen, Protein } \\
\text { C \& S, PT, VWF }\end{array}$ \\
\hline $\begin{array}{l}\text { Cascade }{ }^{\circledR} \text { series } \\
\text { (Helena Laboratories, } \\
\text { USA) }\end{array}$ & Semi & Photo-optical & aPTT, ACT, PT, TT \\
\hline $\begin{array}{l}\text { ACL®) } \\
\text { (Instrumentation } \\
\text { Laboratories, USA }\end{array}$ & Full & $\begin{array}{l}\text { Chromogenic } \\
\text { Immunologic } \\
\text { Nephelometric } \\
\text { Photo-optical }\end{array}$ & $\begin{array}{l}\text { Antithrombin, APC-R, aPTT } \\
\text { TT, Fibrinogen , D-dimer , } \\
\text { Homocysteine, LA, FXIII, } \\
\text { Plasminogen, Protein C \& S, PT, TT, } \\
\text { UFH \& LMWH, VWF }\end{array}$ \\
\hline $\begin{array}{l}\text { KC® series } \\
\text { Destiny® series } \\
(\text { Tcoag, Ireland) }\end{array}$ & Semi; full & $\begin{array}{l}\text { Mechanical } \\
\text { Chromogenic } \\
\text { Immunologic }\end{array}$ & aPTT, TT, Anti-Xa, Fibrinogen, PT \\
\hline
\end{tabular}




\begin{tabular}{|c|c|c|c|c|}
\hline Type of detection & Device (Manufacturer) & $\begin{array}{l}\text { Volume } \\
(\mu \mathrm{l})\end{array}$ & $\begin{array}{l}\text { Type of } \\
\text { withdrawal }\end{array}$ & Comments \\
\hline \multirow{6}{*}{ Optical } & $\begin{array}{l}\text { Hemochron }{ }^{\circledR} \text { Signature }+, \\
\text { Signature Elite (ITC, USA) }\end{array}$ & 15 & $\begin{array}{l}\text { Fingerstick } \\
\text { Venipuncture }\end{array}$ & $\begin{array}{l}\text { Change in fluid oscillation } \\
\text { PT; ACT; aPTT - multiparametric tests } \\
\text { User friendly; quantitative; small sample volume; } \\
\text { handheld/portable; self contained waste channel }\end{array}$ \\
\hline & $\begin{array}{l}\text { Cascade POC (Helena } \\
\text { Laboratories Point of care, USA) }\end{array}$ & 35 & $\begin{array}{l}\text { Fingerstick } \\
\text { Venipuncture }\end{array}$ & $\begin{array}{l}\text { Superparamagnetic oxide particles } \\
\text { PT; ACT; aPTT; Enox } \\
\text { Small sample volume; handheld/portable }\end{array}$ \\
\hline & $\begin{array}{l}\text { ProTime }{ }^{\circledR} \text { Microcoagulation } \\
\text { System (ITC, USA) }\end{array}$ & $\sim 25$ & Fingerstick & $\begin{array}{l}\text { Blood is pumped through the channels } \\
\text { PT/INR } \\
\text { Stores patient data; onboard and external quality controls; } \\
\text { user friendly; handheld/portable }\end{array}$ \\
\hline & $\begin{array}{l}\text { Coag-Sense }{ }^{\mathrm{TM}} \mathrm{PT} / \mathrm{INR} \text { Monitoring } \\
\text { System (CoaguSense Inc., USA) }\end{array}$ & 10 & Fingerstick & $\begin{array}{l}\text { Mechanical principle } \\
\text { PT/INR } \\
\text { Small sample volume; disposable strip; handheld/portable }\end{array}$ \\
\hline & $\begin{array}{l}\text { GEM®PCL Plus (Instrumentation } \\
\text { Laboratory, USA) }\end{array}$ & $\sim 50$ & $\begin{array}{l}\text { Fingerstick for } \\
\text { PT only }\end{array}$ & $\begin{array}{l}\text { Change in fluid oscillation in a test channel } \\
\text { PT; ACT; aPTT } \\
\text { Handheld/portable; maintenance free; automated } \\
\text { measuring and mixing; customised programming options }\end{array}$ \\
\hline & $\begin{array}{l}\text { microINR } ®(\text { iLine Microsystems, } \\
\text { Spain) }\end{array}$ & 3 & Fingerstick & $\begin{array}{l}\text { Microcapillary cessation of flow } \\
\text { PT/INR } \\
\text { Handheld/portable; user friendly; fully automatic }\end{array}$ \\
\hline
\end{tabular}




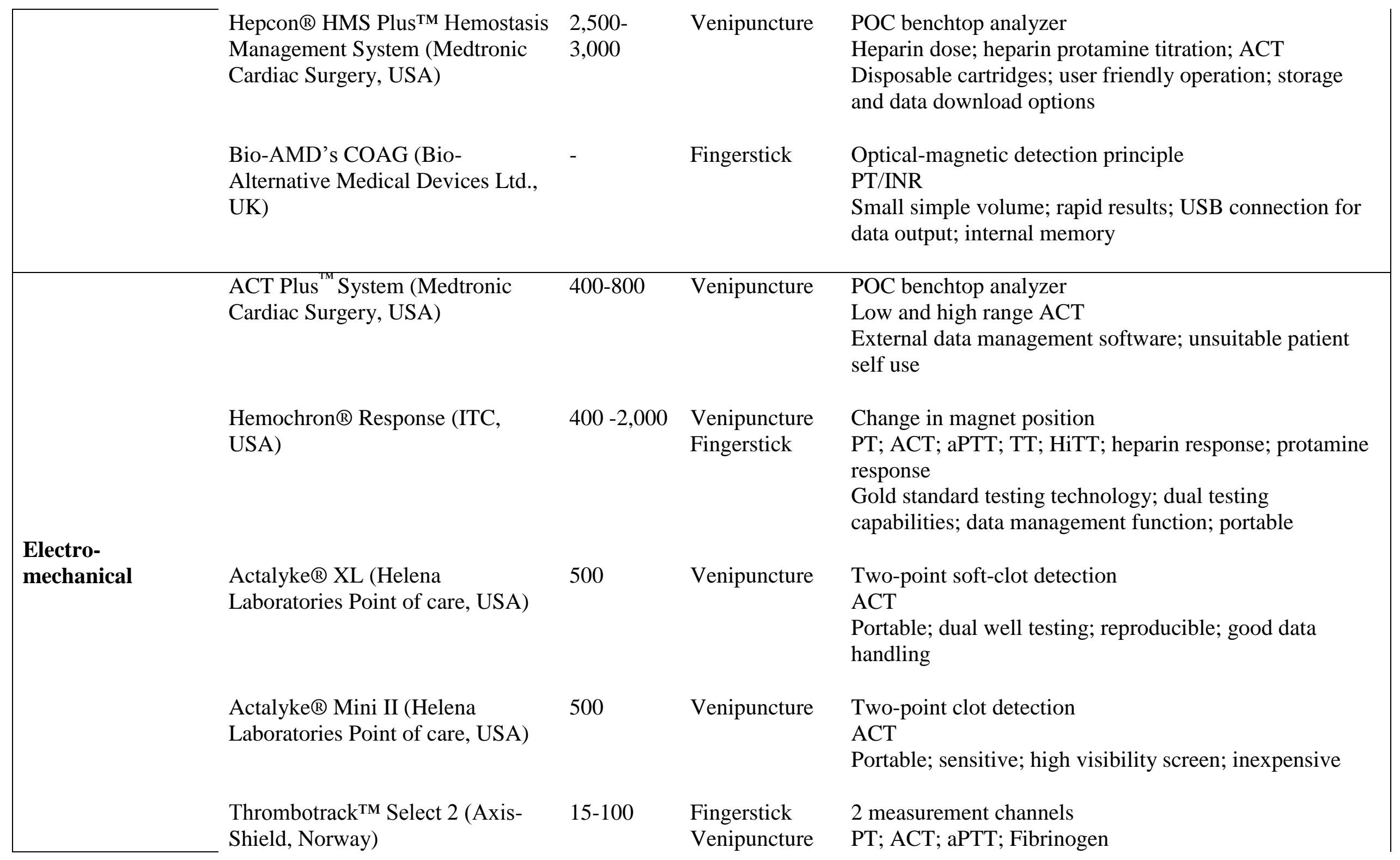




\begin{tabular}{|c|c|c|c|c|}
\hline & & & & $\begin{array}{l}\text { Automatic start upon reagent addition; input of reagent } \\
\text { specific data }\end{array}$ \\
\hline & $\begin{array}{l}\text { Thrombotrack }{ }^{\mathrm{TM}} \text { Solo (Axis- } \\
\text { Shield, Norway) }\end{array}$ & $25-100$ & $\begin{array}{l}\text { Fingerstick } \\
\text { Venipuncture }\end{array}$ & $\begin{array}{l}1 \text { measurement channel } \\
\text { PT; ACT; aPTT; Fibrinogen } \\
\text { Software system controls reaction procedure }\end{array}$ \\
\hline & $\begin{array}{l}\text { CoagLite } ₫ ~ \& ~ C o a g M a x ® \\
\text { (Microvisk Technologies, UK) }\end{array}$ & 5 & $\begin{array}{l}\text { Fingerstick } \\
\text { Venipuncture }\end{array}$ & $\begin{array}{l}\text { MEMS technology } \\
\text { PT/INR } \\
\text { Handheld/portable; in-built quality control checks; data } \\
\text { upload option via USB connection }\end{array}$ \\
\hline \multirow{3}{*}{$\begin{array}{l}\text { Electro- } \\
\text { chemical }\end{array}$} & $\begin{array}{l}\text { i-STAT } \AA(\text { Abbott Point of care } \\
\text { Inc., USA) }\end{array}$ & $17-95$ & $\begin{array}{l}\text { Fingerstick } \\
\text { Venipuncture }\end{array}$ & $\begin{array}{l}\text { Electrogenic } \\
\text { PT/INR; ACT } \\
\text { Handheld/portable; rapid results; data upload to patient } \\
\text { chart; easy to use }\end{array}$ \\
\hline & $\begin{array}{l}\text { INRatio®/INRatio2@ PT INR } \\
\text { Monitor (Alere, USA) }\end{array}$ & $\sim 15$ & Fingerstick & $\begin{array}{l}\text { Changes in impedance } \\
\text { PT/INR } \\
\text { Handheld/portable; large LCD; internal quality controls; } \\
\text { individually wrapped strips for storage at room } \\
\text { temperature; rapid results }\end{array}$ \\
\hline & $\begin{array}{l}\text { CoaguChek® XS, CoaguChek® } \\
\text { XS Plus and XS Pro PT Test } \\
\text { System } \\
\text { (Roche Diagnostics, USA) }\end{array}$ & 8 & $\begin{array}{l}\text { Fingerstick } \\
\text { Venipuncture }\end{array}$ & $\begin{array}{l}\text { Amperometric detection } \\
\text { PT/INR } \\
\text { Handheld/portable; on board quality control; battery } \\
\text { powered; patient/operator identification }\end{array}$ \\
\hline
\end{tabular}




\begin{tabular}{|c|c|c|c|c|}
\hline $\begin{array}{l}\text { Type of } \\
\text { detection }\end{array}$ & Device (Manufacturer) & Sample type & $\begin{array}{l}\text { Volume } \\
(\mu \mathrm{l})\end{array}$ & $\begin{array}{l}\text { Platelet } \\
\text { Function } \\
\text { Device }\end{array}$ \\
\hline \multirow[t]{2}{*}{ Optical } & VerifyNow® (Accumetrics, USA) & $* \mathrm{CWB}$ & $<1,000$ & Genuine POC \\
\hline & $\begin{array}{l}\text { Impact@ Cone and Plate(let) } \\
\text { Analyser (Matis Medical Inc., } \\
\text { Belgium) }\end{array}$ & $* \mathrm{CWB}$ & $\sim 130$ & POC \\
\hline \multirow[t]{2}{*}{$\begin{array}{l}\text { Electrical } \\
\text { impedance }\end{array}$} & $\begin{array}{l}\text { Plateletworks }{ }^{\circledR} \text { (Helena } \\
\text { Laboratories Point of care, USA) }\end{array}$ & $* \mathrm{CWB}$ & 1,000 & $\mathrm{POC}$ \\
\hline & $\begin{array}{l}\text { Multiplate } \AA \text { (Roche Diagnostics, } \\
\text { Switzerland) }\end{array}$ & $\begin{array}{l}\text { Hirudin or } \\
\text { heparin } \\
\text { anticoagulated } \\
\text { WB }\end{array}$ & 300 & POC \\
\hline $\begin{array}{l}\text { Change in } \\
\text { pressure }\end{array}$ & $\begin{array}{l}\text { PFA-100® (Siemens Healthcare } \\
\text { Diagnostics, } \\
\text { Inc., USA) }\end{array}$ & $* \mathrm{CWB}$ & 800 & POC \\
\hline $\begin{array}{l}\text { Electro- } \\
\text { mechanical }\end{array}$ & $\begin{array}{l}\text { TEG® Platelet Mapping }{ }^{\mathrm{TM}} \\
\text { System (Haemonetics, USA) }\end{array}$ & $\begin{array}{l}\text { Heparin } \\
\text { anticoagulated } \\
\text { WB }\end{array}$ & small & POC \\
\hline
\end{tabular}

${ }^{*} C W B=$ Citrated Whole Blood 


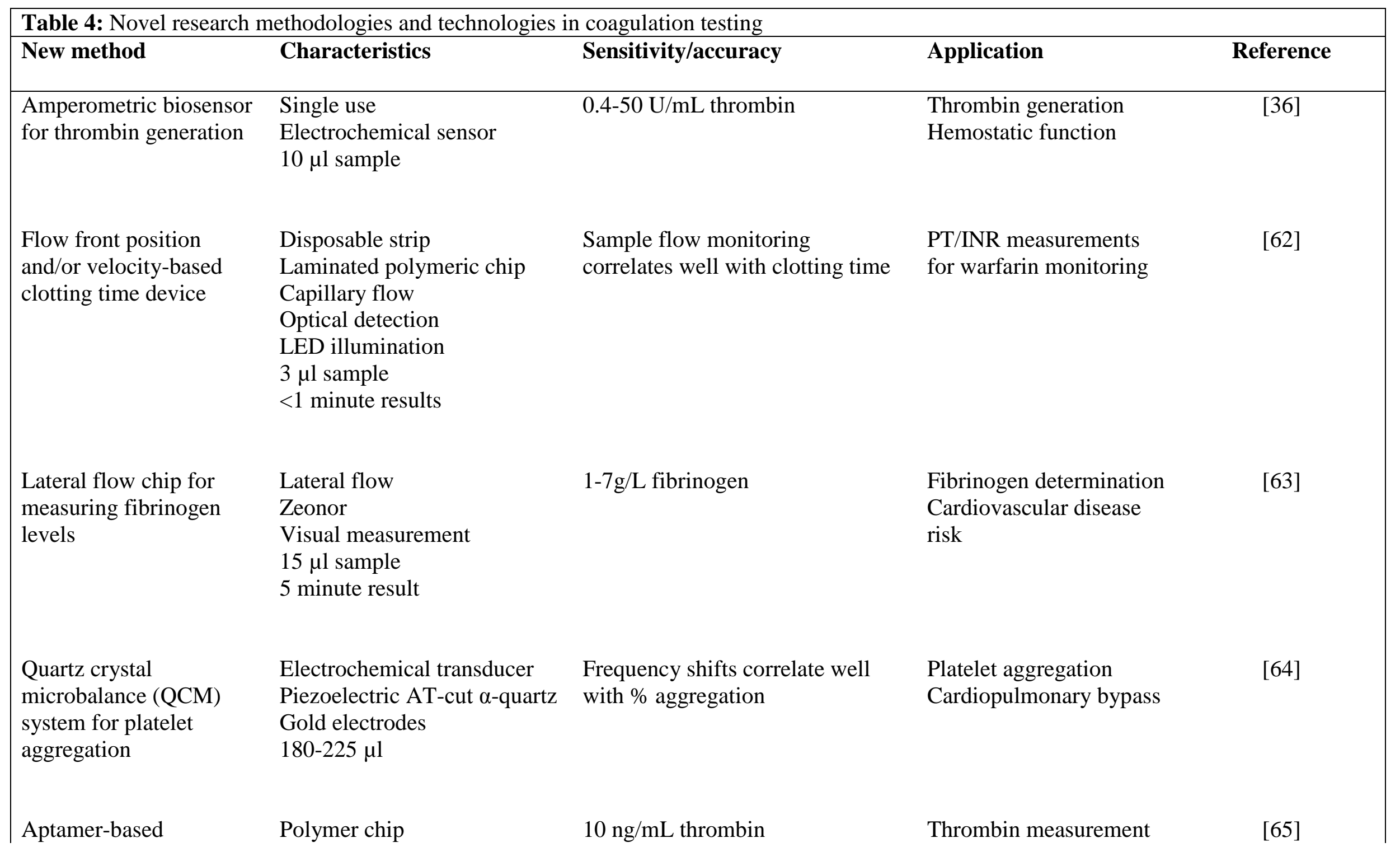


microfluidic chip for

thrombin detection using

magnetic beads and

quantum dots

Microfluidic device for

platelet aggregation

using micro-gradients in

flowing blood

Microstructured lateral

flow chip for fluorescent

detection of clot

formation

Microfluidic impedance

cytometer for platelet

analysis
Pumping

Magnetic beads and quantum

dots

Fluorescence

Polydimethylsiloxane chip $200 \mu$ l sample

Precise control over location of forming aggregates

Epi-fluorescence imaging

Lateral flow chip

Zeonor chip

$25 \mu 1$ sample

Fluorescence

0-2 U/mL heparin

Heparin monitoring

Linearity $\left(\mathrm{R}^{2}=0.99\right)$

Platelet activation (adive adhesive

chip with platinum electrodes

Dielectric focusing

Differential impedance

Spectroscopy

Frequencies of $280 \mathrm{kHz}-4$

$\mathrm{MHz}$

Syringe pumping
Distinguishes between resting

and active platelets

Distinguishes between red blood cells and platelets 

Figure legends
Click here to download Supplementary material: Figure legends.doc 